\title{
Orbán Urbi et Orbi: Christianity as a Nodal Point of Radical-right Populism*
}

\section{Christian Lamour (D) \\ Luxembourg Institute of Socio-Economic Research (LISER)}

\begin{abstract}
There is one European state leader from the moderate Christiandemocrat center right who has developed a discourse and policies showing his progressive move toward the radical right: Viktor Orbán. Can Christianity be considered from a Laclauian perspective, as a "nodal point" of Orbán's radical right discourse; that is, a key element around which his antagonistic narratives are structured? Based on an analysis of segments of Orbán's speeches between 2014 and 2019 that mention Christianity, the research reveals that this religion is a nodal point for three main reasons: (1) the density of Christian references used to shape a negative and antagonistic discourse, strategically adjusted to his audience; (2) the use of Christianity to ground the three ideological pillars of the radical right (populism, nativism, and authoritarianism); and (3) the mobilization of Christianity to organize a hegemonic struggle against the dominant political force that has defined the meaning of this religion in the European public sphere-the moderate center right.
\end{abstract}

\section{INTRODUCTION}

The "thin-centered" populist ideology is based on the opposition between the positive people and the negative elite (Canovan 2004; Mudde 2004; Moffitt 2016). This ideology can be combined with other sets of ideas from socialism, nationalism, and regionalism (Mudde and Rovira Kaltwasser 2013; Taggart 2017; Lamour 2019, 2020; Biancalana and

* This study was supported by the Luxembourg National Research Fund (INTER/SNF/18/ 12618900/CROSS-POP).

Address correspondence and reprint requests to: Christian Lamour, Luxembourg Institute of SocioEconomic Research (LISER), 11, Porte des Sciences, L-4366 Esch-sur-Alzette, Luxembourg. E-mail: christian.lamour@liser.lu 
Mazzoleni 2020), but also with specific religions including Christianity (Zúquete 2008, 2017). Right-wing populist parties in the Western world have notably used Christianity to structure antagonism toward another faith, Islam (Wodak 2015; Minkenberg 2018). This can be especially the case among populist radical-right movements (Mudde 2017).

From a discursive perspective, Christianity can be potentially what Laclau termed a "nodal point" $(2005,103)$ of the populist radical-right discourse. That is, a knot of meanings fixing exclusionary identities based on a set of signifiers; a condensation of meanings, the scope of which is to secure a cultural and political hegemony of populist parties and leaders. It is not generally known, however, under which conditions Christianity can be considered a nodal point of the populist radical-right narratives, and especially those of political leaders. It is argued that this can be the case as long as three parameters are considered: first, the centrality of Christianity to ground key dimensions of populist discourse (negativity and antagonism, the malleable components of the in-group opposed to the out-group depending on the context, and positive references to other populist representatives). Second, a condensation of meanings centered on Christianity, serving to build-up the three ideological pillars of radical right populism (populism, nativism, and authoritarianism). Third, a hegemonic scope of the populist radical right in the public sphere when mentioning Christianity; that is, a struggle against other political forces also using Christianity-a struggle that can also be associated with other representatives of the radical right.

This argumentation is tested by considering the discourse of one the most controversial politicians in power in the European Union, and who has moved progressively to the populist radical right: Viktor Orbán. The Hungarian Prime Minister also has the particularity of grounding his political legitimacy on a political party, the Fidesz, which belonged to the center-right European family of Christian democrat parties, and more precisely the European People's Party (EPP) until March 2021 (Henley 2021). This is despite the multiple condemnations of the policies of the Hungarian leader in his country at the European level for several years (Rankin 2019) and his promoted friendship with other radical-right leaders such as Matteo Salvini of the Italian league (Tondo 2018).

Following a review of the literature on radical-right populism from a discursive perspective, and its links to Christianity, the argumentation and methodology are presented. The use of Christianity as a potential nodal point of Orbán's discourse is analyzed in three parts. First, the scope is to find out whether Christianity is a structuring point of reference, 
around which the Hungarian leader can shape the basis of populist discourse; that is, negativity, the people versus the elite, and the contextbased chameleonic aspect of the in-group opposed to the out-group involving positive references to international figures of the radical right. Second, a qualitative analysis is developed to better grasp if Christianity is constitutive of the three dimensions of the radical right discourse (populism, nativism, and authoritarianism). Third, there is a focus on the possible use of Christianity by Orbán to promote a hegemonic positioning against political forces that have fixed the dominant meaning of this religion in the public sphere.

\section{RADICAL RIGHT POPULISM AND CHRISTIANITY: A DISCURSIVE APPROACH}

Radical-right populism is a specific genre of populism implying not only an opposition between the people and the elite, but also the promotion of nativism and authoritarianism. The core principle of nativism is that a given territory should be peopled by a native and homogenous group protected from alien populations and ideas, whereas authoritarianism is a belief in an ordered society where the strengthening of law and order policies must serve to punish entities contesting authority (Mudde 2017). It is especially by paying attention to the discursive dimension of populism that we can explore its specificities (van Dijk 2013; Wodak 2015; Lamour and Varga 2020; Lamour 2021). The influential work by Laclau on populism as a discourse helps us to explore these characteristics. From a Laclauian perspective, populism is a discourse built up by a proportion of the political elite sensing opportunities to attach exclusionary meanings to the terms "people" and "elite," with a view to maximizing their popular support in a time of crisis and dislocation of dominant ideologies (Laclau 1977, 2005). The "people" and the "elite," as well as other terms linked to them-for instance "workers"- are considered from a Laclauian point of view as "empty signifiers"; that is, elusive words, ideas, and sentences defined with any type of content to shape the conflicting identities of a demarcated in-group and out-group. By contrast, "floating signifiers" are elusive words, ideas, and sentences around which a hegemonic struggle is taking place between competing groups eager to secure and/or contest dominant positions in the definition of these signifiers (Laclau 2005, 103). In parallel, the populist discursive output is characterized by the definition of a "chain of equivalence" 
(Laclau and Mouffe 1985, 144); that is, the association of different demands and identities that can be substituted by one another to construct a demarcation between the in-group and the out-group. The construction of such a chain implies the structural presence of negativity and antagonism to promote the sense of frustration shared by the multi-faceted and majority in-group, opposed to common and small-numbered enemies perceived as upper-level holders of power (the establishment, the intellectuals, the media, etc.). These chains also reveal the chameleonic construction of a dominated in-group opposed to the dominating out-group, the components of which can change over time or depending on contextual elements, such as the type of audience the discourse is addressed to. The populist chain of equivalence assembling a series of evolving empty or floating signifiers is structured around a particular "nodal point"; that is, a privileged discursive point partially fixing the meanings of signifiers within this chain (Laclau and Mouffe 1985). The empty signifier "people" is generally viewed as a central "nodal point" of the populist discourse, binding together the whole population and the plebeians, but it can also be one of the empty signifiers, the meaning of which is determined by another nodal point such as potentially "Christianity," even if such a situation has not been extensively analyzed.

As suggested by Zúquete (2017), it is possible to distinguish two ideal types when a religion such as Christianity is mobilized in populist discourse: the "politicization of religion" and the "sacralization of politics." Each ideal type can be related to the Laclauian approach to populist discourse, as their use implies an affective investment that secures the hegemonic force of discourse (Laclau 2004, 326). Affectivity, the display of feelings and passions, is the necessary driver to win the battle of ideas and moral leadership, as previously mentioned by Gramsci (1971), whose work has influenced Laclau's hegemonic approach to examining populist discourse (Stavrakakis 2017). The politicization of religion leads to multiple uses of religious parameters. One consists of shaping political discourse and actions with a direct link to faith, holy books, and God. Populist stakeholders adopting this vision aim at achieving God's will on earth for their people against threatening enemies; hence there is an affective investment on their part (Stavrakakis 2005; Porter-Szucs 2011). A second strand of the politicization of religion by populist parties and leaders consists of taking religion as a structuring source of cultural identity, the presentation of which also implies the display of emotions and passions. It is particularly used in the European Union to shape conflict with Islam; the defense of a culturally inherited Christian Europe 
being one of the only common denominators among radical-right parties and Identitarian circles in the secularized society of the EU (Caiani 2018; Hafez and Heinisch 2018; Zúquete 2018; Molle 2019; Norris and Inglehart 2019; Schwörer and Romero-Vidal 2020). These expressed Christian-rooted values can be liberal, such as in France or the Netherlands (with a marked distancing from Christian authorities), or conservative, as in Central Europe where populist parties can develop a religious nationalism with the support of top-level clerics (Roy 2016; Arato and Cohen 2017; Brubaker 2017).

The sacralization of politics implies another affective investment from populist forces to secure the hegemonic strength of discourse. It consists of presenting politics as a force of structural transformation linked to myths, rites, and symbols. Sacralization in this way is strongly attached to the totalitarian regimes of the twentieth century (Fascism, Nazism, and Communism). As argued by Zúquete (2017), it is not the essence of religion that secures this second pattern of connections with populism, but its resemblance to it. Here, the antagonist and moral discourse distinguishes the good and moral people from the conspiring and immoral elite, with populist leaders presenting themselves as messianic figures and/or martyrs offering the people a road to salvation in an apocalyptic time thanks to their radical policies while using the language accessible to the man in the street.

Radical-right populist parties and leaders can use a combination of the two ideal types (sacralized politics and politicized religion), potentially making Christianity a discursive nodal point. These positions circulate in a context where there is a strengthening of a culturalist and reactionary intellectual milieu, eager to win the battle of ideas on the building-up of an alternative and Christian-rooted European society within bordered and sovereign states (Buzogány and Varga 2018; Minkenberg 2018; Zúquete 2018). The winning of this battle is further based on the existence of populism as an internationalized process, with populist stakeholders citing and supporting each other at the international level (Caiani 2018). The use of Christianity by the populist right has also emerged in a time of progressive dislocation of the dominant Christian democratic ideology, powered by the non-populist center-right, the role of which has been fundamental in the definition of the European Union (Kaiser 2007). This center-right used Christianity after the Second World War as a broad and moral civilizational ground in a secular era to cut across class and national cleavages and to accommodate conflicts, whereas its nineteenth century and Catholic roots were based essentially on the rejection of liberal democracy 
and the affirmation of the Christian religion (Kalyvas and van Kersbergen 2010). However, this dominant ideology has entered a phase of dislocation, with immigration in Europe coming mainly from Muslim countries. The center-right exists in a European public sphere, where two main alternatives could destabilize their electoral strength and their intellectual and moral leadership on defining Christianity in politics (Kalyvas and van Kersbergen 2010). First, the fostering of accelerated secularization (the deepened promotion of secular values versus religious ones, with an increasingly thinner connection to the religious origin of Christian democracy). Second, religious polarization (the advancement of affirmative Christianity versus Islam, which is normally the position defended by the radical right).

There is one right-wing European leader who has developed a discourse, alliances, and policies clearly associated with the radical right, while still being able to secure the presence of his party in center-right, Christian-democrat political organizations in the Western World: the Hungarian prime minister, Viktor Orbán. ${ }^{1}$ The changing paths taken by Orbán in national and European politics (Waterbury 2006) constitute living proof that populism is the expression of an opportunistic political elite eager to obtain popular support (Laclau 1977, 2005). We can expect Christianity to be incorporated in Orbán's discourse, as he is part of an international Christian-democratic political organization. $\mathrm{He}$ is also supportive of Hungarian Christian churches, which did not oppose his latest radical policies (Fekete 2016; Coman 2019). Nevertheless, can we say that Christianity is a Laclauian "nodal point" of Orbán's radicalright discourse?

\section{ARGUMENT AND METHODOLOGY}

It is argued that Christianity can be considered as a "nodal point" (Laclau 2005) of Viktor Orbán's radical-right discourse as long as it is a central aspect of his discursive output. This implies the use of negativity, antagonism, and the context-based evolution of in-groups opposed to outgroups, as well as the presence of positive ties with other figures of the radical right when Christianity is mentioned. Furthermore, Christianity is also a nodal point of Orbán's discourse as long as it is both a source of legitimation of the three fundaments of the radical right (populism, nativism, and authoritarianism) and a basis of the hegemonic force of his discourse in the broader political spectrum, where the dominant 
meaning of Christian democracy has been defined by the moderate and non-populist center right. These legitimation and hegemonic objectives suppose an affective investment by Orbán; an affective investment deployed through two discursive ideal types: the politicization of religion and the sacralization of politics (Zúquete 2017).

The analysis is based on the speeches produced by the Hungarian Prime Minister between two elections characterized by decisive victories for his party, the Fidesz: the 2014 national election and the 2019 European election. Viktor Orbán is a unique populist political leader, as he is eager to circulate most of his public speeches beyond the limit of Hungary by offering an English (but also sometimes German, French, Spanish, Russian, etc.) translation of them on his website. ${ }^{2}$ All Orbán's speeches made between June 5, 2014 and June 20, 2019, and available in English, were collected, totaling 498. These may not represent all Orbán's public speeches over the period, but they are an exhaustive corpus translated in this language and they reveal a great diversity of discursive contexts, from the national to the international. Potential nuances may exist between the Hungarian speeches and their English translation (defined by the Hungarian administration) as with any translation, but this does not change the structural discursive style of Orbán.

The initial scope was to isolate speeches including words with the prefix "Christ" (with the exclusion of Christmas). That amounts to 218 (44\% of the exhaustive corpus). These speeches have been regrouped into a limited number of categories revealing the existence of different primary audiences to find out potential discursive differences depending on the addressees: (1) a broad audience of Hungarian people (interviews with the Hungarian mass media); (2) a narrow audience of Hungarian people (speeches addressed to smaller communities of Hungarians during, for instance, the opening or re-opening of religious buildings or public and private facilities, factories, and similar, plus other events such as funerals); (3) the Hungarian elite (speeches at national conferences and in parliament involving the presence of top-level public and private stakeholders); and (4) the international elite (speeches at international conferences and diplomatic meetings regrouping international intellectuals, business people, and major political leaders-events sometimes followed or introduced by interviews with the foreign media). ${ }^{3}$ In terms of absolute numbers, it is clearly the international elite that Orbán addresses when mentioning Christianity, but in relative numbers, his main target is the national elite (cf. Table 1). 
Table 1. Distribution of Orbán's speeches by the type of primary audience

\begin{tabular}{|c|c|c|c|}
\hline & $\begin{array}{l}\text { Total number } \\
\text { of speeches }\end{array}$ & $\begin{array}{l}\text { Speeches with } \\
\text { a reference to } \\
\text { Christianity }\end{array}$ & $\begin{array}{c}\text { Proportion of the } \\
\text { "Christianity" speeches } \\
\text { with a negative/antagonist } \\
\text { dimension }(\%)\end{array}$ \\
\hline \multicolumn{4}{|c|}{ Primary audience } \\
\hline \multicolumn{4}{|c|}{ People (Hungarians) } \\
\hline Broad public & 100 & 48 & 90 \\
\hline $\begin{array}{l}\text { Narrow } \\
\text { public }\end{array}$ & 93 & 24 & 50 \\
\hline \multicolumn{4}{|l|}{ Elite } \\
\hline National & 79 & 57 & 58 \\
\hline International & 226 & 89 & 61 \\
\hline Total & 498 & 218 & 65 \\
\hline
\end{tabular}

Note: 48 speeches addressed primarily to a broad public of Hungarians mention Christianity. Some 90\% of them associate Christianity with negative/antagonist argumentation.

In each speech, the shorter segments possibly including words with the prefix "Christ" were isolated; segments where the meaning is clear without reference to the previous and subsequent parts. These segments can vary in length, from one sentence (when, for instance, Orbán simply mentions that Fidesz is a Christian political party) to a maximum of one paragraph, when the Hungarian Prime Minister is keen to develop an argument with a strong Christian connotation, using words with the prefix Christ repeated many times and with the inclusion of references to this religion. A single speech can contain many segments. Orbán can also mention "God" and other religion-related words (e.g., faith) outside the chosen segments. The in-group and out-group mentioned while making reference to Christianity (e.g., migrants and Muslims) can also be present outside the selected segments. However, the scope of the research is to focus on parts of the speeches including a direct reference to Christianity, in order to obtain a more precise set of data on the use of the religion in the discourse of a populist leader. In addition to the date and the place where each speech was given, the following information was encoded in a database at the level of each speech (based on the segments included in it):

1. The presence of negativity and opposition when mobilizing Christianity. That is, negative sentences in terms of content and style revealing the existence of an in-group opposed to an out-group on issues linked to Christianity by Orbán. These issues include a Christian way of life threatened by migrants and Muslims, the presence of risks and the 
legitimate fear of European Christians, and negative labeling of the outgroup opposed to the positive labeling of the Christian-related in-group.

2. The constituents of the in-group as opposed to the out-group. After reading a large number of speeches covering the period, it was possible to isolate different entities of the "we" in-group (Christian Party, Hungarians, Europeans, and Christians) opposed to a "they" out-group (Left Party, Liberal Party, European authorities including Western European states and Brussels-based EU authorities, migrants plus the NGOs defending them, Muslims, and a last group named "Others" including intellectuals, mass media and an undifferentiated "elite").

3. The dimension given to the Christian message. This includes references to the Christian faith (prayers, reference to God, the mention of the word "faith," Orbán's Christian beliefs, etc.) and/or the promotion of the Christian-rooted cultural identity (conservative and/or liberal identities inherited from Christianity with specific attention paid to the family, such as the importance of a mother and father as the nucleus of the family model from a conservative point of view or the Christian-inherited equality between men and women not necessarily respected by migrants from a liberal perspective, children's education implying a Christianinherited culture, etc.). The aim was to find out if Orbán adapts his speeches to the changing context of Christianity in the Western world; a religion that is practiced less, but potentially used as a point of cultural reference by populist stakeholders to root their nativist argumentation and to extend their popular support.

4. References to international figures of right-wing populism presented positively, and the presence of other international-like figures identified negatively when producing narratives mobilizing Christianity. The aim of this was to find out if Christianity is used in his speeches to display his belonging to the global right-wing populist community.

Following this broad encoding of information, a critical discourse analysis (CDA) was carried out on a selection of segments, enabling us to grasp the nuanced approach to Christianity as a source of antagonism in Orbán's discourse. The objective is to look at how Christianity is used to:

(1) enrich Orbán's radical-right narratives based on populism, nativism, and authoritarianism,

(2) offer a vision of "Christian Democracy" in a political public sphere where this type of democracy has been defined in Europe since WW2 by centerright political forces. 
CDA is particularly appropriate to reveal the structure and sequences of opposition between groups constructed by populist politicians in their discourses (van Dijk 2013). As the nomination of these groups has already been considered by the quantitative approach to discourse, the objectives when analyzing specific segments is to pay more precise attention to the three other dimensions of the CDA as presented by Richardson and Wodak (2013): (1) the perspectivation (the position and involvement of the speaker); (2) the predication (the labeling of the antagonist in-group and out-group); and (3) the argumentation (the common sense justification of this labeling organized around thematic topoi). CDA is a qualitative methodology that can be supplemented by a quantitative survey gathered through corpus linguistics methodology (Mautner 2005). This involves the annotation, abstraction, and analysis of a textual sample and hence was used for the primary encoding of information on the selected speeches given by Orbán.

\section{LISTENING TO THE IRREGULAR “CHRISTIAN HEARTBEATS” OF A RADICAL RIGHT POPULIST}

The importance of Christianity in the speeches by Orbán over a long period of time (218 speeches- $44 \%$ of the total—with a steady increase over the years $)^{4}$ and its association with a conflictual vision of society makes this religion a "nodal point" of his radical right discourse. The broad investigation of the 218 speeches, followed by a CDA of a selection of texts to approach this religion as a basis of his radical right ideology and a source of his hegemonic struggle in the public sphere, help us to explore the meaning of Christianity as a nodal point of Orbán's discourse.

\section{Let there be Antagonism: Discursive Tendencies and Strategic Adjustments Depending on Audiences and Contexts}

Budapest is the urbem (city) from which Orbán issues the majority of his Christian-related speeches, followed by a series of cities in central Europe and then more rarely urban capitals elsewhere, such as Brussels, Strasbourg, Madrid, or even Teheran. However, his discourse is aimed at a Christian orbem (world) going far beyond the limits of Hungary and central Europe and with a clear conflictual dimension. Two-thirds of Orbán's speeches with a reference to Christianity are used with negativity and antagonism, with a strong variation depending on the audience 
showing the strategic adjustment of the populist Hungarian leader (Table 1). It is particularly when he addresses a mass audience of national Hungarian people that the proportion of speeches linking Christianity and antagonism is the highest. Orbán is seen as a promoter of national populism. However, his use of Christianity does not involve a basic opposition of "good" Christian Hungarians versus "bad" Muslim migrants in a country where Muslims account for $0.4 \%$ of the whole population (Pew Research Center 2017).

A structural opposition is visible in all his speeches whatever his audience. Christianity is the nodal point around which "chains of equivalence" are structured with a clear battleground: Europe (Tables 2 and 3).

Orbán's discursive horizon is made up of two antagonistic forces linking different signifiers. On one hand is the "in-group" of Hungarians, Christians, Christian Parties, and Europeans, used in a simplistic way as common/interchangeable communities supposed to represent the "people" and its representatives; on the other hand, an "out-group" of European authorities (mainly Western European States and Brussels-based EU public bodies) and extra-European migrants with whom NGOs are sometimes associated. Orbán is keen on putting more emphasis on European authorities than on the "elite" (including the Mass Media and the intellectuals) and opposing political parties (left/liberal) when shaping most of his populist antagonism involving Christianity. It is important to note that most of his anti-Western countries and Brussels speeches are made in Central Europe for a Central European audience (Hungarian people and the governments of this part of Europe, including many rightwing populist ones such as in the Visegrad countries). Migrants are only the most central "out-group" when Orbán circulates his messages to a broad public of Hungarians via the media; the affective investment and fear factor associated with threatening masses of migrants being probably more effective to reach a mass audience of fellow nationals. Muslims are mentioned as a clear out-group, but to a far lesser extent than the non-religion connoted "migrants" and European authorities. Whatever the audience, they are mentioned in half as many selected texts compared with migrants and European authorities. Nevertheless, Muslims are always associated with negativity and antagonism when mentioned together with Christianity.

It is important to add that Orbán can on some occasions present positive populist models and negative figures when mentioning words with the prefix Christ. The most visible proof of his belonging to the international right-wing populist community is the positive references to the leaders of 
Table 2. In-groups and positive references to foreign right-wing populist figures in speeches associating Christianity with negativity/antagonism

\begin{tabular}{|c|c|c|c|c|c|c|}
\hline & \multirow{2}{*}{$\begin{array}{l}\text { Number of the "Christianity" } \\
\text { speeches with a negative/ } \\
\text { antagonist dimension }\end{array}$} & \multicolumn{4}{|c|}{ In-groups } & \multirow{2}{*}{$\begin{array}{l}\text { Speeches with positive } \\
\text { references to foreign } \\
\text { right- wing populist } \\
\text { leaders }\end{array}$} \\
\hline & & Party members & Hungarians & Christians & Europeans & \\
\hline \multirow{2}{*}{\multicolumn{7}{|c|}{ Primary audience }} \\
\hline & \multicolumn{6}{|c|}{ People (Hungarians) } \\
\hline Broad public & 43 & $26(60 \%)$ & $21(49 \%)$ & $27(63 \%)$ & $24(56 \%)$ & $1(2 \%)$ \\
\hline Narrow public & 12 & $4(33 \%)$ & $8(66 \%)$ & $8(67 \%)$ & $7(58 \%)$ & 0 \\
\hline \multicolumn{7}{|l|}{ Elite } \\
\hline National & 33 & $12(36 \%)$ & $16(48 \%)$ & $26(79 \%)$ & $15(45 \%)$ & $2(6 \%)$ \\
\hline International & 54 & $23(43 \%)$ & $24(44 \%)$ & $37(69 \%)$ & $32(59 \%)$ & $3(6 \%)$ \\
\hline Total & 142 & $65(46 \%)$ & $69(49 \%)$ & $98(69 \%)$ & $78(55 \%)$ & $6(4 \%)$ \\
\hline
\end{tabular}

Note: Some 26 speeches addressed to a broad public of Hungarians and including narratives mentioning Christianity with a negative/antagonist argumentation signal "party members" as a "we" in-group. This represents $60 \%$ of all "Christian negativity" speeches targeting this audience. 
Table 3. Out-groups and negative references to foreign-like figures in speeches associating Christianity with negativity/ antagonism

\begin{tabular}{|c|c|c|c|c|c|c|c|c|}
\hline & \multirow[b]{2}{*}{$\begin{array}{l}\text { Number of the } \\
\text { "Christianity" } \\
\text { speeches with a } \\
\text { negative/ } \\
\text { antagonist } \\
\text { dimension }\end{array}$} & \multicolumn{4}{|c|}{ Out-groups } & \multirow[b]{2}{*}{ Muslims } & \multirow[b]{2}{*}{$\begin{array}{c}\text { Others } \\
\text { (Intellectuals/ } \\
\text { Mass Media/ } \\
\text { "Elite") }\end{array}$} & \multirow[b]{2}{*}{$\begin{array}{c}\text { Speeches with } \\
\text { negative } \\
\text { references to } \\
\text { foreign-like } \\
\text { stakeholders }\end{array}$} \\
\hline & & $\begin{array}{c}\text { Left } \\
\text { party }\end{array}$ & $\begin{array}{c}\text { Liberal } \\
\text { party }\end{array}$ & $\begin{array}{l}\text { European authorities } \\
\text { (Western Countries/ } \\
\text { "Brussels" EU } \\
\text { authorities) }\end{array}$ & Migrants & & & \\
\hline \multicolumn{9}{|c|}{ Primary audience } \\
\hline Broad public & 43 & $8(19 \%)$ & $6(14 \%)$ & $13(30 \%)$ & $23(53 \%)$ & $7(16 \%)$ & $1(2 \%)$ & $8(19 \%)$ \\
\hline Narrow public & 12 & 0 & $1(10 \%)$ & $6(50 \%)$ & $2(20 \%)$ & $2(20 \%)$ & 0 & 0 \\
\hline \multicolumn{9}{|l|}{ Elite } \\
\hline National & 33 & $3(1 \%)$ & $6(2 \%)$ & $16(48 \%)$ & $18(55 \%)$ & $7(21 \%)$ & $2(1 \%)$ & $8(24 \%)$ \\
\hline International & 54 & $6(11 \%)$ & $9(17 \%)$ & $25(46 \%)$ & $27(50 \%)$ & $16(30 \%)$ & $4(7 \%)$ & $1(2 \%)$ \\
\hline Total & 142 & $17(12 \%)$ & $22(15 \%)$ & $60(42 \%)$ & $70(49 \%)$ & $32(23 \%)$ & $7(5 \%)$ & $17(12 \%)$ \\
\hline
\end{tabular}

Note: Eight speeches addressed to a broad public of Hungarians and including narratives mentioning Christianity with a negative/antagonist argumentation signal "Left Party" as a "they" out-group. This represents 19\% of all "Christian negativity/antagonism" speeches targeting this audience. 
liberal (e.g., Silvio Berlusconi) and radical-right populism (e.g., Matteo Salvini). These people are mentioned only once or twice and never in the presence of Muslim or Western European leaders in conference rooms, whereas someone in particular is represented negatively 16 times when mentioning Christianity, a person mentioned exclusively in Hungarian mass media or in front of the Hungarian elite: George Soros, the Hungarian-born financier and philanthropist living in the United States. Georges Soros is not presented as the anti-Christ, but he is viewed as the man conspiring and encouraging the influx of migrants who will destroy the Hungarian, Christian, and European way of life. Soros is placed in the realm of the antagonized Christian cultural identity.

Orbán has been seen as favoring religious institutions in Hungary, in particular to manage education (Fekete 2016). Nevertheless, he is not overly keen on promoting the Christian faith when mobilizing words with the prefix Christ, as this is the case in less than a quarter of his speeches. Orbán is more eager to promote a Christian cultural identity and its association with the construction of families, for example the education of children or equality between men and women (Table 4). By doing so, he shows the strategic adjustment of populist leaders preferring to use Christianity as a cultural background rather than a faith to found their nativist argumentation and to reach the maximal popular support in countries where traditional religious practice is on the

Table 4. Christian values in speeches associating Christianity with negativity/ antagonism

\begin{tabular}{lcrr}
\hline & $\begin{array}{c}\text { Number of the "Christianity" } \\
\text { speeches with a negative/ } \\
\text { antagonist dimension }\end{array}$ & \multicolumn{2}{c}{ Christian values } \\
\cline { 3 - 4 } & & \multicolumn{1}{c}{ faith } & culture \\
\hline $\begin{array}{l}\text { Primary audience } \\
\text { People (Hungarians) }\end{array}$ & & & \\
$\quad$ Broad public & 43 & $10(23 \%)$ & $32(74 \%)$ \\
$\quad$ Narrow & 12 & $7(58 \%)$ & $8(67 \%)$ \\
$\quad$ public & & & \\
Elite & 33 & $9(27 \%)$ & $28(85 \%)$ \\
$\quad$ National & 54 & $12(22 \%)$ & $36(67 \%)$ \\
$\quad$ International & 142 & $38(27 \%)$ & $104(73 \%)$ \\
Total & & & \\
\hline
\end{tabular}

Note: 10 speeches addressed to a broad public of Hungarians and including narratives mentioning Christianity with a negative/antagonist argumentation signal "faith" as a value associated with Christianity. This represents $23 \%$ of all "Christian negativity" speeches targeting this audience. 
decline. The expression "way of life" associated with Hungarians, Europeans, and Christians-and opposed to that of migrants and Muslims-is cited 76 times in the 218 speeches considered in this analysis. The following parts help to grasp more qualitatively how Orbán uses Christianity as a structuring element of his radical-right discursive positioning based on two ideal-types: the sacralization of politics and the politicization of religion.

\section{Populism, Nativism, and Authoritarianism: An Approach of the Magyar Radical-right Gospel}

Orbán is keen on circulating sacralized politics, and especially so when he starts or finishes his speeches (sometimes ending with the Latin quote Soli Deo Gloria). ${ }^{5}$ This type of discourse associated with his vision, involvement, and interpretation of situations (the perspectivation as presented by Richardson and Wodak 2013) shows that Orbán generally prefers to place himself within a collective "we," the implicit definition of which can change depending his audience and the issues (Hungarians, Christian believers, party members, or Europeans, with the focus sometimes on Central European people, etc.), alternatively he constructs sentences using the impersonal pronoun "it." This impersonal form of sacralized politics can be found for instance in the 2017 Fidesz Congress, during which he also asked in a Trumpian way to "make Europe great again." As can be seen in the extract below from one of his speeches, his sacralized politics are based on the emotionally-rich myth of origin (Hungarians of the steppes) to which the Christian-inherited positive labeling of Hungarians is related ("the love of humanity and respect for human freedom"), whereas the opponents of Hungary in Europe ("some countries") are associated with negative labeling: the non-respect of "fundamental Christian principles." Orbán always keeps a low profile and offers his audience a subliminal-like topos of savior (Wodak 2015) implying an affective investment. Opposite to the chain of equivalence "post-Christian" or "post-national" countries (two empty signifiers), it leaves no doubt he will be the one "continuing on the path mapped out by fundamental Christian principles of life" and following the "moral truths that are independent of time and place" (two other empty signifiers), even if his narrative is limited to the antagonist choice existing in Europe, of Christian versus post-Christian: 
Our political community knows that the Hungarian nation was the product of an encounter between the Eastern character and Western culture [...]. The love of freedom represented by the steppes met the peace and truth of the Christian faith; and out of this grew a love of humanity and respect for human freedom, which to this day stand at the centre of our political thinking in Hungary. [...] All this seems natural, and even sounds good. But there is a catch. In Europe some countries decided to forsake Christianity, and to forsake their own national identity. They want to enter a post-Christian and post-national era. Today it is clear that we give different answers to the question of whether we should continue on the path mapped out by fundamental Christian principles of life and by national cultures, and whether we still believe in moral truths that are independent of time and place. ${ }^{6}$

The people versus the elite narratives associated with radical-right populism are largely substituted by people versus Western Europe/Brussels/ some countries when the Hungarian Prime Minister refers to Christianity, as previously mentioned. The politicized religion in his radical-right narratives also has a strong nativist dimension. Three different dangers are portrayed, helping to define the emotionally charged Christianity-loving native Hungarians and native Europeans, rooted in national communities requiring protection. The first of these dangers are societal models viewed as outside of the traditional Christian family comprising one father and one mother, with an occasional direct criticism of the "third gender" (Hungarian Government 2017a) and his professing to "remain how God created you. True to your nationality, sex and faith" (Hungarian Government 2017b); a rejection of the trans community having subsequently entered the legal terrain in Hungary (Walker 2020). Orbán adopts a conservative vision of society and Christianity associated with Central and Easter European populism. The "good" native Christians are also opposed to the migrants and the Muslims. It is not the faith of the natives that is at stake here, but their Christian-inspired "way of life" compared with practicing Muslims having a different way of life, as apparent in some Western European radical right rhetoric. The migrants arriving in Europe are usually labeled negatively and associated with a natural danger or disaster involving water by Orbán (e.g., "flooding," "rising tide of migrant masses," "mass migration is like a slow and steady current of water which washes away the shore," and "if the dam wall bursts, the water will flood in on us").

The attitude toward Muslims is more complex. Orbán professes a respect for the religion and a condemnation of anti-Muslim acts in 
Hungary, but he also constructs a viewpoint in which Christianity and Islam are bounded to two parallel societies that can at best co-exist in Europe, but with multiple references to the danger posed by Islam to a Christian Europe. The Hungarian Prime Minister is keen on combining two specific topoi on which to base the Christian nativism: first, the topos of reality (e.g., "it takes a vivid imagination to believe that young Afghan men will marry into traditional German Christian families or Christians into Muslim families en masse [...] the harsh reality is that the greater the cultural divide, the greater the chance of conflict and clashes") (Hungarian Government 2016). Second, the topos of number (e.g., "from then on sheer mathematics comes in to play, and because they [Muslims] have higher birth rates, are more family-centred [...] If we allow a competition to evolve between two civilisations [Christian - Muslim] here, in Europe, we Christians will lose") (Hungarian Government 2015). This nativism is developed in particular in the Hungarian media and is generally absent when Orbán addresses a foreign elite during international conferences involving Muslim countries and representatives from Western Europe.

The last aspect of the radical right, the promotion of authoritarianism, is focused on the securitization of state borders to prevent the ingress of migrants and/or Muslims whose attitudes are not respectful of the Christian-inherited legal system (e.g., monogamy) and pose a danger to different categories of a secularized society (e.g., women, although not LGBT members), without forgetting the risk of terrorism. The word "border" is one of those most cited by Orbán in the 218 speeches considered (940 times), and generally associated with securitized control to reinforce an ordered society of law-abiding Christian, Hungarian, and European people. Christianity is not only a nodal point to promote his radical-right positioning, but also an instrument to contest the "intellectual and moral leadership" (Gramsci 1971, 193) of the dominant vision of Christianity in the European political space by offering a new hegemonic order. That is, a born-again illiberal Christian Democracy favored by the strengthened culturalist and reactionary intellectual milieus in Europe (Buzogány and Varga 2018; Zúquete 2018).

\section{Christian Democracy as a Floating Signifier: In Illiberalism "We" Trust}

Orbán's political party, Fidesz, from which he secures his executive power, is generally not defined as a Christian democrat party 
(Grzymala-Busse 2011). However, it has been part of supranational political organizations regrouping this type of party: the European People's Party (EPP) in the European Parliament until March 2021 and the global Centrist Democrat International (CDI) that Orbán continues to call the "Christian Democrat International" (Hungarian Government 2018a). "Christian Democracy" and "Christian Democrats" are central in his narratives. He uses one of these two terms 168 times in the 218 speeches. "Christian Democracy" is a "floating signifier" (Laclau 2005), around which Orbán chooses to engage in a hegemonic struggle with the dominant political force that has set the meaning of Christian democracy in the public sphere: the moderate center right.

Orbán's logic is quite clear: to impose a new definition of European Christian democracy. First, by linking himself to its charismatic and moderate leader over recent decades-Helmut Kohl—who, after his death, was spoken about by Orbán with profound reverence on different occasions. Second, by offering a diverging path to the one professed since WW2 by this political family; that is, a Christianity used in party politics as a civilizational heritage to heal conflicts in a secular and politically liberal era, implying a distancing from its nineteenth-century origin and its rejection of liberal democracy (Kalyvas and van Kersbergen 2010). Orbán goes back to this origin of Christian democracy. Christian Democracy as a floating signifier can form a chain of equivalence with the empty signifier "illiberal democracy," which is also a central term in Orbán's speeches.

By linking himself to Helmut Kohl, Orbán promotes sacralized politics implying an affective investment as suggested in the speech quoted from below. As seen in this discourse, Christianity associated with the deceased man is opposed to "European (political) correctness," and Kohl is metaphorically presented as an old, almost biblical, shepherd looking after a new generation of Christian democrats to whom Orbán belongs; a generation not moved by conflict healing and moderation of the center right, but by affirmative Christianity. Once again, Orbán disappears behind a collective "we," grieving the death of "our" chancellor when circulating narratives of sacralized politics:

This was a political ceremony. That fact can be sensed especially clearly when you consider that, for instance, the word "Christianity" was not even mentioned - even though we are burying a Christian democratic politician. So everyone spoke in accordance with the rules of political correctness, as is the permitted custom in the building of the European Parliament. $[\ldots]$. The truly moving and spiritual farewell to our Chancellor will be held 
tonight, in the Cathedral. [...] he shepherded our generation, if you like, with the love of a grandfather towards seeing that there are fashions, which come and go, but there is a single secure location on which a Europe of values can be built: that location being Christianity. ${ }^{7}$

Orbán's politicized religion when addressing Christian democracy is based on a dual discursive strategy: first, the separation of Christian democracy from the liberal environment within which it is currently located, and second, the dismissal of the current European People's Party and its central member (the German CDU of Angela Merkel whose decision to accept a massive number of migrants in Germany is indirectly opposed by the Hungarian leader criticizing the "Willkommenskultur" of European leaders) as a source of the definition of Christian democracy. Orbán exploits the difficulties of today's centerright Christian Democratic movement in Europe facing two opposite choices potentially leading to their collapse: increased secularization or religious polarization (Kalyvas and van Kersbergen 2010). He does so by putting all his weight behind the second option, while always emphasizing a Christian (conservative) identity rather than a Christian faith, even if he can sometimes mingle the two.

His decision to support Christian democratic illiberalism and religious polarization makes him a direct ally of the European radical right. Orbán is ready to promote this approach at the international level through foreign mass media or during international conferences of Christian democrats. However, he strategically adjusts his discourse to prevent his exclusion from center-right circles. His hegemonic struggle within the moderate center right is based on indirect support for the right-wing populist community. This was exemplified during the CDI conference on interfaith dialog held in Budapest in 2018 (Hungarian Government 2018a) and again during the international conference held in the memory of Helmuth Kohl. During the latter, he affirmed that the EPP and Christian democrats should not be "anti-populist" and against "the emerging new parties," which anyone can guess is intended to mean the radical-right ones like the German AfD, as all the other political forces are mentioned against these "new parties" (Hungarian Government 2018b). Sometimes, he can directly mention support for radical-right leaders, especially when he is interviewed by foreign reporters, as shown in the discourse below. Here, the labeling of the EPP and the French far right by Orbán leave no doubt about his preferences (EPP equals Left versus Le Pen equals Christian values), which is reinforced 
with a topos of consequence (Wodak 2015) to delegitimize the current EPP as a source of "intellectual and moral leadership" in order to define the meaning of Christianity in politics (if EPP and its members continue to go to the left, then they will lose their Christian identity and values):

Christian democrats in Europe, in particular, in Germany are shifting towards the left. If things continue like this, and they continually enter into coalition with the Left, the socialists, then they will have to make compromises and will lose their identity and values. [...] I see great opportunities in the parties which are gaining in strength-as you say-on the peripheries. They represent Christian values, though they do not call themselves Christian democrats [...] They [Mrs. Le Pen's party] do not want Islam to make gains. They see Christian culture as a priority, defend families and the nation state. I like these notions, but in the People's Party this provoked criticism because the EPP would like to go left. ${ }^{8}$

This link to the radical right is reaffirmed in his many definitions of Christian democracy, which is often contrasted with liberal democracy in an antagonist way. The labeling of these two views of democracy shows where his preferences lie, as proved in the speech quoted from below that combines two "chains of equivalence": Christian Democracy is $\mathrm{A}, \mathrm{B}, \mathrm{C}$, whereas Liberal Democracy is $\mathrm{X}, \mathrm{Y}, \mathrm{Z}$; two chains related through the topos of opposite (Wodak 2015). Christian Democracy and Liberal Democracy are two conflicting options in the public sphere because the empty signifiers $\mathrm{A}, \mathrm{B}, \mathrm{C}$ are the respective opposites of the empty signifiers $\mathrm{X}, \mathrm{Y}, \mathrm{Z}$ :

Let us confidently declare that Christian democracy is not liberal. Liberal democracy is liberal, while Christian democracy is, by definition, not liberal: it is, if you like, illiberal. [...] Liberal democracy is in favour of multiculturalism [A], while Christian democracy gives priority to Christian culture [X]; this is an illiberal concept. Liberal democracy is pro-immigration [B], while Christian democracy is anti-immigration [Y]; this is again a genuinely illiberal concept. And liberal democracy sides with adaptable family models $[\mathrm{C}]$, while Christian democracy rests on the foundations of the Christian family model [Z]; once more, this is an illiberal concept. ${ }^{9}$

The hegemonic dimension of Orbán's discourse when he mobilizes Christianity is also expressed through his connection to the world of the struggling elite. For him, winning the battle of ideas involving 
Christianity is about the replacement of the dominant elite ("we must show that the liberal elite can be replaced with a Christian democratic elite," Hungarian Government 2018c). Orbán likes to portray himself as a "country boy," a "wrestler," or a "street fighter." However, his party (Fidesz) is close to the Szazadveg Foundation conservative intellectual circle (Buzogány and Varga 2018), and the Hungarian "country boy" is looking for an illiberal Christian-based elitist legitimacy. Orbán can even proclaim that this struggle for power within the elite can be hidden from the Hungarian people based on the topos of uselessness ("This doesn't need to disrupt the daily lives of Hungarians, because it has no effect on them"). One may wonder how a political regime and its intellectual bases can have no effect on people's daily lives:

We are not liberals, and we are not building a liberal democracy: we are building a Christian democracy, which has European traditions and which has European roots. There is a great debate about this, a debate which is essentially of an intellectual nature [...] This doesn't need to disrupt the daily lives of Hungarians, because it has no effect on them. But the intellectual sphere is also an important one, and there too one must interpret what a government does and why it does it. Here we are working on building a Christian democracy. ${ }^{10}$

\section{CONCLUDING DISCUSSION}

Viktor Orbán is a right-wing political leader who has succeeded in securing increasing popular electoral support by developing discourses and a political program that denotes his belonging to the international radical right. Christianity can be considered as a nodal point of his radical-right discourse, as it is: (1) a central element to shape a strategically adjusted in-group versus out-group antagonism; (2) a basis for his populist, nativist, and authoritarian positioning; and (3) a key component to organize a hegemonic struggle in the public sphere around the floating signifier "Christian Democracy." The politicization of religion and the sacralization of politics (Zúquete 2017) are the two discursive ideal types around which Orbán constructs his Christian-based narratives; narratives charged with an affective investment to secure their hegemonic force (Laclau 2005). What makes Orbán so characteristic in the sphere of European populist leaders when he uses Christianity as a nodal point?

First, he tends to go beyond the people versus elite opposition associated with the radical right to secure his international dimension. He 
rescales his Christian-related discourse beyond the level of the Hungarian state, by focusing on a European in-group opposed to an out-group that is actually no less European. This out-group is strongly associated with Western European countries and EU authorities, representing the frustrating or troublesome upper-level power holders going against the interests of state-bounded people termed "Europeans," "Christians," and "Hungarians." This substitution of the elite by an upper-level sphere of political decision-making is normally characteristic of some regional populist parties in Western Europe (Taggart 2017; Lamour 2020). It shows that national populist leaders from medium-size countries may choose this meta-political regional strategy to increase their popular support and their leading role among the populist parties and identitarian circles of Europe (Zúquete 2018). The migrants and the Muslims are out-groups opposed to Europeans, Christians, and Hungarians, but the key frustration is due to the presence of hegemonic and liberal power holders in the European Union that do not prevent the arrival of migrants and Muslims and consequently fail to preserve the Christian-inherited European "way of life." This insistence on European power holders opposed to Europeans can be a key dimension of the Christian-based radical-right discourse beyond the more traditional antagonism between Christian-rooted Europeans and Muslims that is analyzed in some panEuropean academic works (Schwörer and Romero-Vidal 2020).

Second, the discourse of the Hungarian prime minister is characterized by a multi-faceted strategic adjustment, depending on the type of audience. The emotionally charged fear factor associated with migrants representing a threat to Europeans, Christians, and Hungarians is far more important when Orbán addresses a mass audience of Hungarian voters to secure the maximum popular support at different elections. This choice is relevant, coming from a leader whose ethno-national populism has often been mentioned (Fekete 2016). In parallel, when in conferences with representatives of Western European countries, he stops himself from labeling these in a negative out-group, and in front of Muslim leaders, he will also avoid presenting Muslims as being opposed to Christians. However, these international events can still be times during which he can put forward his Christian illiberalism preferences by showing his support for radical-right parties and leaders of the Western world (based on their supposedly shared vision of a Christian culture under threat), and by condemning the political correctness of the non-populist centerright Christian democrats. He sees himself as a bridge between these two right-wing groupings by changing the meaning of the floating 
signifier "Christian democracy" within a moderate center right. The hegemonic scope of Orbán is made possible because the non-antagonistic and dominant Christian ideology of the center right has entered a phase of dislocation in the current secularized Europe, which is in parallel peopled by a growing Muslim community (Kalyvas and van Kersbergen 2010). Orbán's discourse in these international and moderate center-right circles can be considered relatively successful, as his party-Fidesz-is still a member of the CDI and was pushed to leave the EPP only in March 2021 in spite of the progressive collapse of the liberal democracy in Hungary over the years and his portrayed friendship with the European radical right.

Third, Orbán presents himself as a Christian believer, who follows traditional religious practices. Nevertheless, he knows that the secularization process at home and in the broader Europe mean these Christian religious practices are on the decline. Consequently, he makes a strategic adjustment by preferring to use Christianity as a cultural background rather than a faith to found his nativist argumentation in the way other opportunistic populist leaders do, especially those in Western Europe (Roy 2016; Arato and Cohen 2017; Brubaker 2017; Minkenberg 2018; Norris and Inglehart 2019). This strategic adjustment can be considered successful at home, but also in the EU and within the EPP until March 2021. Orbán and his election-winning discourse ${ }^{11}$ on the Christian-based European "way of life" might have been influential in the decision by the current European Commission (the presidents of which have come from the EPP since 2004) to announce a vice-presidency in charge of migration, security, and dialog with religions "protecting our European way of life"12; a decision perceived as a concession to, or an ideological victory by, some radical-right parties (Carraud 2019; Trilling 2019).

\section{NOTES}

1. https://www.idc-cdi.com/

2. http://www.kormany.hu/en/the-prime-minister/the-prime-minister-s-speeches

3. The speeches addressed to the Hungarian and international elite can also circulate to a foreign and Hungarian audience through the mass media (e.g., interviews with foreign reporters or speeches in front of large audiences of Hungarians located abroad). However, they are always produced "live" in front of a public characterized by its belonging to the elite or with the background of foreign political elite - the overhearing audience (Heritage 1985) — eager to know what Orbán is going to say to a mass audience in his country. The speeches produced for a narrower audience of Hungarians can include members of the elite (e.g., the clerical hierarchy when opening churches or at the burial of Hungarian stakeholders), but they are also scenes where the non-elite can be present. It is a small community of Hungarian people that is targeted by Orbán.

4. From 6 and 38 speeches respectively during the last 6 months of 2014 and the whole of 2015 , to 59 and 29 respectively in 2018 and the first 6 months of 2019. 
5. Glory to God alone.

6. Hungarian Government (2017a). "Prime Minister Viktor Orbán's speech at the 27th Congress of Fidesz-Hungarian Civic Union.” Retrieved from www.miniszterelnok.hu.

7. Hungarian Government (2017c). "Viktor Orbán's interview with MTVA." Retrieved from www. miniszterelnok.hu.

8. Hungarian Government (2019). "Interview with Prime Minister Viktor Orbán in the Austrian newspaper Kleine Zeitung." Retrieved from www.miniszterelnok.hu.

9. Hungarian Government (2018c). "Prime Minister Viktor Orbán's speech at the 29th Bálványos Summer Open University and Student Camp." Retrieved from www.miniszterelnok.hu.

10. Hungarian Government (2018d). "Prime Minister Viktor Orbán on the Kossuth Radio programme '180 Minutes'." Retrieved from www.miniszterelnok.hu.

11. Following the 2019 elections, Fidesz became the third most important political group of the dominant center-right European People's Party (EPP), whereas Hungary is only the 13 largest country in the EU (Mudde 2019).

12. https://ec.europa.eu/commission/commissioners/2019-2024/schinas_en.

\section{REFERENCES}

Arato, Andrew, and Jean L. Cohen. 2017. "Civil Society, Populism and Religion." Constellations (Oxford, England) 24:283-295.

Biancalana, Cecilia, and Oscar Mazzoleni. 2020. "Unifying and Multiplying the People: The Strategy of Ambiguity in National-Populist Discourse within a Cross-Border Area." Nationalism and Ethnic Politics 26(3):279-298.

Brubaker, Rodgers. 2017. "Between Nationalism and Civilizationism: The European Populist Moment in Comparative Perspective." Ethnic and Racial Studies 40 (8):1191-1226.

Buzogány, Aron, and Mihai Varga. 2018. "The Ideational Foundations of the Illiberal Backlash in Central and Eastern Europe: The Case of Hungary." Review of International Political Economy 25(6):811-828.

Caiani Manuela. 2018. "Radical Right Cross-National Links and International Cooperation." In The Oxford Handbook of the Radical Right, ed. Jens Rydgren. Oxford: Oxford University Press, 394-411.

Canovan, Margaret. 2004. "Populism for Political Theorists?" Journal of Political Ideologies 9(3):241-252.

Carraud Simon. 2019. "France's Le Pen Hails EU 'Way of Life' Job as Victory on Path to Elysee." Available at: https://www.reuters.com/article/us-france-politics-farrightiduskbn1w00n2 15.09.2019

Coman Julian. 2019. "The Pastor versus the Populist: Hungary's New Faith Faultline." Available at: https://www.theguardian.com/world/2019/dec/29/pastor-v-populist-viktororban-hungary-faith-faultline

Fekete, Liz. 2016. "Hungary: Power, Punishment and the 'Christian-National Idea'." Race \& Class 57(4):39-53.

Gramsci, Antonio. 1971. Selections From the Prison Notebooks. London: Lawrence \& Wishart.

Grzymala-Busse, Anna. 2011. "Why there is (Almost) no Christian Democracy in PostCommunist Europe." Party Politics 19(2):319-342.

Hafez, Farid, and Reinhard Heinisch. 2018. "Breaking with Austrian Consociationalism: How the Rise of Rightwing Populism and Party Competition Have Changed Austria's Islam Politics." Politics and Religion 11(13):649-678, doi: 10.1017/S1755048318000172.

Henley Jon. 2021. "Hungary's Fidesz Party to Leave European Parliament Centre-right Group". Available at: https://www.theguardian.com/world/2021/mar/03/hungarysfidesz-party-to-leave-european-parliament-centre-right-group 
Heritage John. 1985. "Analyzing News Interviews: Aspects of Talk for an Overhearing Audience." In Handbook of Discourse Analysis Vol. 3, ed. Teun Van Dijk. New York, NY: Academic Press, 95-119.

Hungarian Government. 2015. "Interview with Prime Minister Viktor Orbán on Commercial Station Tv2's 'Facts-Evening' Television Programme." Available at: www.miniszterelnok.hu

Hungarian Government. 2016. "Provided there are Christians, There Will be a Spiritual Upturn." Available at: www.miniszterelnok.hu

Hungarian Government. 2017a. "Prime Minister Viktor Orbán's Speech at the 27th Congress of Fidesz-Hungarian Civic Union." Available at: www.miniszterelnok.hu

Hungarian Government. 2017b. "Prime Minister Viktor Orbán's Speech at the Rededication of the Protestant Theological Institute, Kolozsvár (Cluj).” Available at: www.miniszterelnok.hu

Hungarian Government. 2017c. "Viktor Orbán's Interview with MTVA.” Available at: www. miniszterelnok.hu

Hungarian Government. 2018a. "Prime Minister Viktor Orbán’s Speech at Christian Democrat International's Conference on Interfaith Dialogue." Available at: www.miniszterelnok.hu

Hungarian Government. 2018b. "Prime Minister Viktor Orbán's Speech at a Conference Held in Memory of Helmut Kohl." Available at: www.miniszterelnok.hu

Hungarian Government. 2018c. "Prime Minister Viktor Orbán's Speech at the 29th Bálványos Summer Open University and Student Camp." Available at: www.miniszterelnok.hu

Hungarian Government 2018d. "Prime Minister Viktor Orbán on the Kossuth Radio Programme '180 Minutes'." Available at: www.miniszterelnok.hu

Hungarian Government. 2019. "Interview with Prime Minister Viktor Orbán in the Austrian Newspaper Kleine Zeitung." Available at: www.miniszterelnok.hu

Kaiser, Wolfram. 2007. Christian Democracy and the Origins of the European Union. Cambridge, UK: Cambridge University Press.

Kalyvas, Stathis N., and Kees Van Kersbergen. 2010. "Christian Democracy.” The Annual Review of Political Science 13:183-209.

Laclau, Ernesto. 1977. Politics and Ideology in Marxist Theory: Capitalism-FascismPopulism. Atlantic Highlands, N.J.: Humanities Press.

Laclau, Ernesto. 2004. "Glimpsing the Future," In Laclau. A Critical Reader, eds. C Simon and Oliver M, New York: Routledge, 279-328.

Laclau Ernesto. 2005. On Populist Reason. London: Verso. p. 103

Laclau, Ernesto, and Chantal Mouffe. 1985. Hegemony and Socialist Strategy. London: Verso.

Lamour, Christian. 2019. "Mass media and Border Securitization in Europe: Investigating the Metropolitan 'Mediapolis' in an era of Right-Wing Populism." Journal of Urban Affairs 41(4):535-550.

Lamour, Christian. 2020. "The League of Leagues: Meta-Populism and the "Chain of Equivalence' in A Cross-Border Alpine Region.” Political Geography 81:102207, https://doi.org/10.1016/j.polgeo.2020.102207.

Lamour, Christian. 2021. "Interviewing a Right-Wing Populist Leader During the 2019 EU Elections: Conflictual Situations and Equivocation Beyond Borders." Discourse \& Communication 15(1):59-73.

Lamour, Christian, and Renáta Varga. 2020. "The Border as a Resource in Right-Wing Populist Discourse: Viktor Orbán and the Diasporas in a Multi-Scalar Europe." Journal of Borderlands Studies 35(3):335-350.

Mautner, Gerlinde. 2005. "Time to Get Wired: Using Web-Based Corpora in Critical Discourse Analysis." Discourse \& Society 16(6):809-828.

Minkenberg, Michael. 2018. "Religion and the Radical Right," In The Oxford Handbook of the Radical Right, ed. J., Rydgren, Oxford: Oxford University Press, 366-393. 
Moffitt, Benjamin. 2016. The Global Rise of Populism: Performance, Political Style, and Representation. Palo Alto, CA: Stanford University Press.

Molle, Andrea. 2019. "Religion and Right-Wing Populism in Italy: Using 'Judeo-Christian Roots' to Kill the European Union." Religion, State \& Society 47(1):151-168.

Mudde, Cas. 2004. "The Populist Zeitgeist." Government and Opposition 39(4):541-563.

Mudde, Cas. 2017. "Introduction to the Populist Radical Right," In The Populist Radical Right. A Reader, ed. C., Mudde, London: Routledge, 1-10.

Mudde Cas. 2019. "The Far Right may not have Cleaned up, but its Influence Now Dominates Europe." Available at https://www.theguardian.com/commentisfree/2019/ may/28/far-right-european-elections-eu-politics

Mudde, Cas, and Rovira Kaltwasser Cristóbal. 2013. "Populism," In The Oxford Handbook of Political Ideologies, eds. M., Freeden, L. T., Sargent and M., Stears, Oxford: Oxford University Press, 493-512.

Norris, Pippa, and Ronald Inglehart. 2019. Cultural Backlash. Trump, Brexit, and Authoritarian Populism. Cambridge: CUP.

Pew Research Center. 2017. 5 Facts about the Muslim Population in Europe.

Porter-Szucs, Brian. 2011. Faith and Fatherland: Catholicism, Modernity and Poland. New York: Oxford University Press.

Rankin Jennifer. 2019. "EU Leaders Must do more to Save Rule of Law in Hungary, Says MEP." Available at: https://www.theguardian.com/world/2019/jan/30/eu-leaders-mustdo-more-to-save-rule-of-law-in-hungary-says-mep

Richardson, John E., and Ruth Wodak. 2013. "The Impact of Visual Racism: Visual Arguments in Political Leaflets of Austrian and British Far-right Parties," In Critical Discourse Analysis. Volume IV. Applications, Interdisciplinary Perspectives and New Trends, ed. R., Wodak, London: Sage, 245-274.

Roy, Olivier. 2016. "The French National Front: From Christian Identity to Laicité," In Saving The People: How Populists Hijack Religion, ed. N., Marzouki, D., Mcdonnell and O., Roy, London: Hurst Publishers, 79-93.

Schwörer, Jakob, and Xavier Romero-Vidal. 2020. "Radical Right Populism and Religion: Mapping Parties' Religious Communication in Western Europe." Religion, State and Society 48(1):4-21.

Stavrakakis, Yannis. 2005. "Religion and Populism in Contemporary Greece," In Populism and the Mirror of Democracy, ed. F., Panizza, London: Verso, 224-249.

Stavrakakis Yannis. 2017. "Populism and Hegemony." In The Oxford Handbook of Populism, eds. Cristobal Rovira Kaltwasser, Paul Taggart, Paulina Ochoa Espejo and Pierre Ostiguy. Oxford: Oxford University Press, 535-553.

Taggart, Paul. 2017. "Populism in Western Europe," In The Oxford Handbook of Populism, ed. C. R., Kaltwasser, P., Taggart, P. O., Espejo and P., Ostiguy, Oxford: Oxford University Press, 248-264.

Tondo Lorenzo. 2018. "Matteo Salvini and Viktor Orbán to Form Anti-Migration Front." Available at: https://www.theguardian.com/world/2018/aug/28/matteo-salvini-viktororban-anti-migrant-plan-brussels

Trilling Daniel. 2019. "'Protecting the European Way of Life' from Migrants is a Gift to the Far Right." Available at: https://www.theguardian.com/commentisfree/2019/sep/13/ protecting-europe-migrants-far-right-eu-nationalism

Van Dijk, Teun A. 2013. "Ideology and Discourse," In The Oxford Handbook of Political Ideologies, ed. M., Freeden, L. T., Sargent and M., Stears, Oxford: Oxford University Press, 728-740.

Walker Sean. 2020. "Hungary Prepares to End Legal Recognition of Trans People." Available at: https://www.theguardian.com/world/2020/apr/26/hungary-prepares-toend-legal-recognition-of-trans-people 
Waterbury, Myra A. 2006. "Internal Exclusion, External Inclusion: Diaspora Politics and Party-Building Strategies in Post-Communist Hungary." East European Politics and Societies 20(3):483-515.

Wodak, Ruth. 2015. The Politics of Fear: What Right-Wing Populist Discourses Mean. Los Angeles, CA: Sage.

Zúquete, José P. 2008. "The European Extreme-Right and Islam: New Directions?" Journal of Political Ideologies 13(3):321-344.

Zúquete, José P. 2017. "Populism and Religion," In The Oxford Handbook of Populism, ed. C. R., Kaltwasser, P., Taggart, P. O., Espejo and P., Ostiguy, Oxford: Oxford University Press, 445-466.

Zúquete, José P. 2018. The Identitarians. The Movement Against Globalisation and Islam in Europe. Notre Dame, Indiana: Notre Dame University Press.

Christian Lamour is a researcher in urban, cultural, and border studies. He pays attention to political discourse with a focus on the populist one and in relation with the European Union integration at different spatial scales. 